\title{
RULE 1, REVISION 30-TO PREVENT THE SPREAD OF SPLENETIC OR TICK FEVER IN CATTLE
}

\author{
- Effective on and after December 1, 1931
}

\section{United States Departament of Agriculture, OFFTCE OF THE SECRETARY.}

The fact has been determined by the Secretary of Agriculture and notice is hereby giren that the contagious and infectious disease known as splenetic or tick ferer exists in cattle in Ouachita Parish, La., and that said mentioned disease still exists among cattle in other portions of the State of Louisiana, and also in the following States and Territory, to wit: Arkansas, Florida, Texas, and Porto Rico.

Now, therefore, I, Arthur M. Hyde, Secretary of Agriculture, under authority conferred by section 1 of the act of Congress approved March 3, 1905 (33 Stat. 1264), do hereby quarantine the areas hereinafter described, and do order by this rule 1 , revision 30 , under the authority and discretion conferred on the Secretary of Agriculture by section 3 of the said act of Congress, approred March 3, 1905 (33 Stat. 1265), that the interstate movement of cattle from the areas herein quarantined shall be made only in accordance with the regulation of the Secretary of Agriculture for the prevention of the spread of splenetic or tick ferer in cattle.

\section{AREAS QUARANTINED}

The following areas are quarantined for splenetic or tick fever in cattle:

\section{ARKANSAS}

The following counties and portion of a county are quarantined: Ashley, Bradley, Calhoun, Chicot, Drew, Ouachita, and Union, and that portion of Desha County south of the Arkansas Rirer.

\section{FLORIDA}

The following counties and portion of a county are quarantined: Brevard, Charlotte, Citrus, Collier, De Soto, Glades, Hardee, Hendry, Hernando, Highlands, Hillsborough, Indian River, Lee, Manatee, Okeechobee, Orange, Osceola, Pasco, Pinellas, Polk, St. Lucie, Sarasota, Seminole, and Sumter, and that part of Lake County lying south of the boundary line between township 17 south and township 18 south.

\section{LOUISIANA}

The following parishes and portions of parishes are quarantined: Acadia, Allen, Aroyelles, Beauregard, Bienville, Bossier, Cameron, Calcasieu, Caldwell, Catahoula, De Soto, Erangeline, Franklin, Grant, Iberia, Jackson, Jefferson Davis, Lafayette, La Salle, Livingston, Morehouse, Natchitoches, Ouachita, Pointe Coupee, Rapides, Richland, Red River, Sabine, St. Helena, St. Landry, St. Martin, St. Tammany, Tangipahoa, Union, Vermilion, Vernon, Washington, Webster, West Carroll, and Winn; that portion of Ascension Parish lying north and east of the Mississippi River; and that portion of Iberville Parish lying west of the Mississippi River.

\section{PORTO RICO}

The entire territory is quarantined. 


\section{TEXAS}

The following counties and portions of counties are quarantined: Anderson, Angelina, Atascosa, Austin, Brazos, Brooks, Burleson, Cameron, Chambers, Cherokee, Duval, Galveston, Grimes, Hardin, Harris, Hidalgo, Houston, Jasper, Jefferson, Jim Hogg, Jim Wells, Kenedy, La Salle, Leon, Liberty, Live Oak, McMullen, Madison, Milam, Montgomery, Nacogdoches, Newton, Orange, Panola, Polk, Robertson, Rusk, Sabine, San Augustine, San Jacinto, Shelby, Starr, Trinity, Tyler, Walker, Waller, Washington, Webb, Willacy, and Zapata; that part of Brazoria County lying east of the Brazos River ; and that part of Fort Bend County lying east of the Brazos River.

\section{INTERPRETATION}

This rule 1 , revision 30 , shall be construed in connection with the regulation of the Secretary of Agriculture for the prevention of the spread of splenetic or tick fever in cattle, and is subject to amendment or revision on statutory notice.

Rule 1, revision 29 (B. A. I. Order 328), dated November 4, 1930, effective December 1,1930 , shall cease to be effective on and after December 1, 1931, on and after which date this rule 1 , revision 30 , which for purposes of identification is designated as B. A. I. Order 332 , shall become and be effective until otherwise ordered.

The effect of this order is as follows:

In Arkansas: Cleveland, Columbia, Dallas, Hempstead, Lafayette, Lincoln, and Nevada Counties are released from quarantine.

In Florida: Alachua, Flagler, Marion, Putnam, St. Johns, and Volusia Counties; the remainder of Duval County; and that part of Lake County lying north of the boundary line between township 17 south and township 18 south, are released from quarantine.

In Louisiana: that part of Ouachita Parish, east of the Ouachita River, formerly released, is requarantined.

In Texas: Dimmit, Freestone, Frio, and Lee Counties; the remainder of Limestone County; that part of Brazoria County lying west of the Brazos River; and that part of Fort Bend County lying west of the Brazos River, are released from quarantine.

The existing quarantine in the territory of Porto Rico is continued.

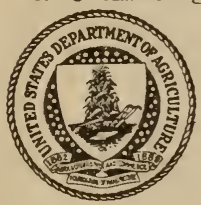

Done in the City of Washington, this 7 th day of November, 1931.

Witness my hand and the seal of the Department of Agriculture.

ARTHUr AI. HỸe, Secretary of Agriculture.

\section{NOTE:}

\section{FEEDING STATIONS FOR NONINFECTED CATTLE}

Properly equipped, noninfectious pens are maintained at the following points within the quarantined area :

ARKANSAS

McGehee, Desha County, Ark., Missouri Pacific Railroad Co. pens.

\section{FLORIDA}

Fort Pierce, St. Lucie County, Fla., Florida East Coast Rallway pens.

\section{LOUISIANA}

Alexandria, Rapides Parish, La., Missouri Pacific Railroad and the Texas \& Paciflc Railway pens.

De Quincy, Calcasieu Parish, La., Gulf Coast Line pens.

TEXAS

Beaumont, Jefferson County, Tex., Gulf, Colorado \& Santa Fe Railway Co. pens.

Beaumont, Jefferson County, Tex.. Southern Pacific Co. pens.

Bellville, Austin County, Tex., Gulf, Colorado \& Santa Fe Railway Co. pens.

Conroe, Montgomery County, 'Tex., Gulf, Colorado \& Santa Fe Railway Co. pens.

(Englewood) Houston, Harris County, Tex., Southern Pacific Railway Co. pens.

Houston, Harris County, Tex., Port City Stockyards pens.

Hearne, Robertson County, Tex., Houston \& Texas Central Railroad pens.

Laredo, IVebb County, Tex., International \& Great Northern Railway pens.

Orange, Orange County, Tex., Southern Pacific Lines pens.

Palestine, Anderson County, Tex., International \& Great Northern Railway pens. 